\title{
Isolation of Host Specific Endophytic Fungus, Fusarium Equiseti, from Nothopegia Bedomei, Wayanadica Occurring in the Southern Parts of India
}

\author{
Thulasi G. Pillai*, Bharath Nair and G.E. Mallikarjuna Swamy \\ Department of Forest Pathology, Kerala Forest Research Institute, Peechi, Thrissur-680653, Kerala
}

\begin{abstract}
Fusarium equiseti was isolated from the leaves, of the endangered forest tree, Nothopegia bedommei, wayanadica. Fusarium is a large genus of filamentous fungi which belongs to the of class sordariomycetes, distributed in soil and in association with plants, mostly symptomless. Cultural and morphological characterisation of the organism was done. True endophytes have been evolving with the host for millions of years. This organism can have an important role in the survival and protection of the plant against harsh environment and adverse conditions.
\end{abstract}

Keywords: Endophytic fungi; Nothopegia bedomei, Fusarium equiseti; Western Ghats

\section{Introduction}

Endophytes are microorganisms that live inside the host plant tissues without causing symptoms of disease which [1]. Ubiquitous in nature, endophytes can contribute to their host plant by producing a plethora of substances that provide protection and ultimately survival value to the plant. The compounds have potential for use in modern medicine, agriculture, and industry [2]. Novel antibiotics, antimycotics, immunosuppressants, and anticancer compounds are only a few examples of what has been found after the isolation and culturing of individual endophytes followed by purification and characterization of some of their natural products.

Nothopegia beddomei Gamble var wynaadica belongs to Anacardiaceae family [3]. It is endemic to Southern Western Ghats. This species is known only from a single site in Wayanad near the border with Karnataka. The tree is found in low and medium elevations in semi-evergreen and evergreen forests.

\section{Materials and Methods}

Collection of samples: Leaves were collected from at random, during the months of April (pre-monsoon), May (monsoon) and October (post-monsoon) 2013-2014. Sixty healthy leaves were sampled in each sampling time. The latitude and longitude of collection site are $\mathrm{N} 11^{\circ} 43^{\prime} 59^{\prime \prime}$ and E $76^{\circ} 5^{\prime} 59^{\prime \prime}$. Average temperature is $27.3^{\circ} \mathrm{C}$ and average rainfall is $3187 \mathrm{~mm}$.

Isolation of endophytes: Endophytic fungi was isolated by the method of Muthukumar [4]. The samples were processed within 24 $\mathrm{hr}$ of collection. The samples were washed thoroughly in running water, surface sterilized in $70 \%$ ethanol for $3 \mathrm{~min}$ and washed in sterile water for 20s. Sixty segments of leaf $(0.5 \mathrm{~cm}$ diameter $)$, were placed on Oat Meal Agar (OMA) amended with streptopenicillin. The cultures were incubated at room temperature $(26 \pm 2 \mathrm{C})$ in $12 \mathrm{~h}$ light and 12 dark cycles of 28 days. The tissue segments were observed daily for fungal growth and the isolates were scored and transferred to OMA slants for preservation. From among the isolates, a white fungus with pigmentation showed host-specificity. Cultural characteristics of all the fungi isolated were recorded.

Colonies: 15 different colonies were obtained with colours ranging from gray, white and pink. Among the colonies obtained, one of the cultures was found to be frequently occurring in all the sampling, and was considered as host-specific. The host specific fungus was fast growing, with pink cottony mycelium. Macro and micro conidia was observed from slender phialides. Macroconidia were hyaline, two to several celled, fusiform to sickle shaped mostly with elongated apical cell and pedicellate basal cell. Microconidia were 1 to 2 celled hyaline, pyriform, fusiform to ovoid, straight and curved. The other 14 cultures were infrequent and were considered as casual endophytes.

SEM studies: Scanning electron microscopy was performed using the techniques described by Ezra et al [5]. After processing, the fungal material was dried, coated with gold by sputtering technique and examined under JEOL 6100 SEM (Figure 1).

\section{Results}

Fungal endophytes: 15 cultures were obtained. The tissue cultures constantly yielded one endophyte, which was identified as Fusarium

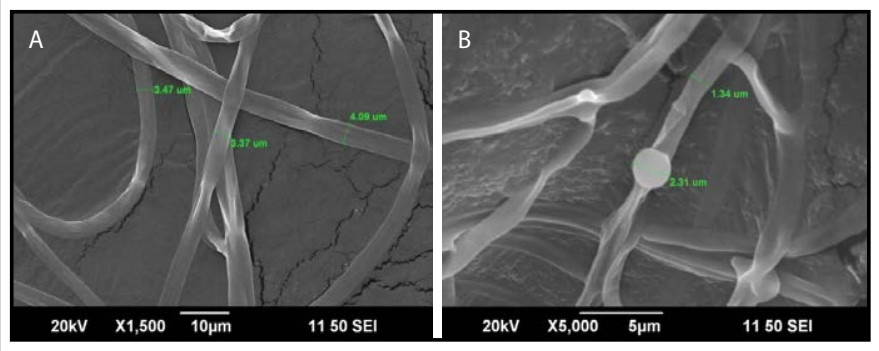

a. Hyphae

b. Chlamydospores

Figure 1: Scanning electron microscopic image of Fusarium equiseti,

*Corresponding author: Thulasi G Pillai, Department of Forest Pathology, Kerala Forest Research Institute, Peechi, Thrissur-680653, Kerala, Tel: +91-4872690100; E-mail: thulasigpillai@gmail.com

Received September 28, 2015; Accepted October 12, 2015; Published October 15,2015

Citation: Pillai TG, Nair B, Swamy GEM (2015) Isolation of Host Specific Endophytic Fungus, Fusarium Equiseti, from Nothopegia Bedomei, Wayanadica Occurring in the Southern Parts of India. J Plant Pathol Microb 6: 308. doi:10.4172/2157. 7471.1000308

Copyright: ( 2015 Pillai TG, et al. This is an open-access article distributed under the terms of the Creative Commons Attribution License, which permits unrestricted use, distribution, and reproduction in any medium, provided the original author and source are credited. 
Citation: Pillai TG, Nair B, Swamy GEM (2015) Isolation of Host Specific Endophytic Fungus, Fusarium Equiseti, from Nothopegia Bedomei, Wayanadica Occurring in the Southern Parts of India. J Plant Pathol Microb 6: 308. doi:10.4172/2157-7471.1000308

Page 2 of 2

equiseti. The fungus was recovered from during all seasons. Other isolates viz., Aspergillus niger, Phomopsis sp. Rhizopus sp. and several other strains of white, gray sterile mycelium were infrequent and not isolated in all seasons (Table 1). Hence, Fusarium equiset i is apparently the only host-specific endophyte of the plant.

\section{Discussion}

Fusarium equiseti, a weak pathogen, is a soil-inhabiting fungal species that colonize plant roots, also a natural root endophyte [6] that can colonize plant roots and possess characters that makes it a promising candidate for biological control of root pathogens and nematodes. As a pathogen, reports are there for Fusarium as the causative agent of Bakanae disease with a complex of disease symptoms including seedling blight, root and crown rot, stunting, and the classic symptoms of etiolation and abnormal elongation induced by the fungal production of gibberellin hormones [7-9]. Fusarium equiseti is also reported to act against parasitic plants such as Striga hermonthica [10]. Fusarium equiseti is reported to inhibit gram-positive bacteria [11].

F. equiseti is capable of synthesising a vast range of phytotoxic and cytotoxic secondary metabolites. [12,13], like trichothecenes: 4-acetylnivalenol, nivalenol, scirpentriol and numerous other mycotoxins, such as zearalenone, beauvericin, fusarochromanone, equisetine and butenolide [14]. There are reports for the production of a new enniatin antibiotic from the endophyte Fusarium tricinctum Corda [15]. Fusarium usually dominates root endophytic communities specialised for the colonisation of herbaceous plants [16] suggesting the importance of the roots as an endophytic niche for Fusarium species. Symptomless endophytic colonization of maize by Fusarium moniliforme has been reported by Bacon, [17].

Nothopegia beddomei, Wynaadica is an endangered tree endemic to Kerala part of Western Ghats. No reports are available about this species until now. We have isolated different compounds from F. equiseti, and the therapeutic studies of the compounds isolated are in progress.

\begin{tabular}{|c|c|c|c|}
\hline \multirow{2}{*}{ Fungi/Location } & \multicolumn{3}{|c|}{ Wayanad } \\
\hline & April & June & October \\
\hline Fusarium equiseti & + & + & + \\
\hline A.niger & + & + & - \\
\hline Phomopsis sp. & - & + & - \\
\hline Rhizopus sp. & - & + & + \\
\hline Sterile white mycelium* & + & - & + \\
\hline Sterile grey mycelium* & - & + & + \\
\hline
\end{tabular}

${ }^{*}$ Contains a group of 32 morphotypes none of which were isolated constantly from any season.; +, present; -, absent.

Table 1: Fungal endophytes from $N$. beddomei wynaadica.

\section{References}

1. Selosse MA, Baudoin E, Vandenkoornhuyse $P$ (2004) Symbiotic microorganisms, a key for ecological success and protection of plants. C R Biol 327: 639-648.

2. Strobel G, Daisy B, Castillo U, Harper J (2004) Natural products from endophytic microorganisms. J Nat Prod 67: 257-268.

3. Ellis, Chandra. (Bull. Bot. Surv. India12: 257. 1970). FI. Pres. Madras 1: 265 1918; Gamble, FI. Madras 1: 265. 1997 (re. ed); Saldanha, FI. Karnataka 2 207. 1996; Sasidharan, Biodiversity documentation for Kerala- Flowering Plants, part 6: 112. 2004; Keshava Murthy and Yoganarasimhan, FI. Coorg (Kodagu)125. 1990

4. Muthukumar T, Udaiyan K (2000) Arbuscular mycorrhizas of plants growing in the Western Ghats region, Southern India. Mycorrhiza 9: 297-313.

5. Ezra D, Hess WM, Strobel GA (2004) New endophytic isolates of Muscodor albus, a volatile-antibiotic-producing fungus. Microbiology 150: 4023-4031.

6. Marcia-Vicente JG, Jansson HB, Abdullah SK, Descols E, Salinas J (2008a) Fungal endophytes from natural vegetation in Mediterranean environments with special reference to Fusarium species. FEMS Microbiology Ecology 64 90-105.

7. Nicholson P, Simpson DR, Weston G, Rezanoor HN, Lees AK (1998) Detection and quantification of Fusarium culmorum and Fusarium graminearum in cereals using PCR assay. Plant Pathol 53: 17-37.

8. Sun SK, Snyder WC (1981) The bakanae disease of the rice plant. In PE Nelson, TA Toussoun, and RJ Cook (ed.), Fusarium: diseases, biology and taxonomy. The Pennsylvania State University Press, University Park, pp: 104-113

9. Webster RK, Gunnell PS (1992) Compendium of rice diseases. The American Phytopathological Society Press, St. Paul, Minn.

10. Kirk AA (1993) A fungal pathogen with potential for biocontrol of Striga hermonthica (Scrophulariaceae). BioControl 38: 459-460.

11. Burmeister HR, Bennett GA, Vesonder RF, Hesseltine CW (2009) Antibiotic Produced by Fusarium equiseti NRRL 5537. New Phytologist 182: 213-228.

12. Langseth W, Bernhoft A, Rundberget T, Kosiak B, Gareis M (1998) Mycotoxin production and cytotoxicity of Fusarium strains isolated from Norwegian cereals. Mycopathologia 144: 103-113.

13. Morrison E, Rundberget T, Kosiak B, Aastveit AH, Bernhoft A (2002) Cytotoxicity of trichothecenes and fusarochromanone produced by Fusarium equiseti strains isolated from Norwegian cereals. Mycopathologia 153: 49-56.

14. Thrane $U$ (1989) Fusarium species and their specific profiles of secondary metabolites. In: Chelkowski J, editor. Fusarium-mycotoxins, taxonomy and pathogenicity. Amsterdam: Elsevier pp: 199-226.

15. Zaher AM, Makboul MA, Moharram AM, Tekwani BL, Calderón Al (2015) A new enniatin antibiotic from the endophyte Fusarium tricinctum Corda. J Antibiot (Tokyo) 68: 197-200.

16. Sieber TN (2002) Fungal root endophytes. In: Waisel Y, Eshel A, Kafkafi U, editors. Plant roots: The hidden half. New York/Basel: Marcel Dekker pp: 887-917.

17. Bacon CW, Hinton DM (1996) Symptomless endophytic colonization of maize by Fusarium moniliforme. Canadian Journal of Botany 74: 1195-1202. 